\title{
Computer Simulation Model System for Interpretation and Validation of Algorithms for Monitoring of Cancer Patients by Use of Serial Serum Concentrations of Biomarkers in the Follow-Up After Surgical Procedures and Other Treatments - A Computer Simulation Model System Based on the Breast Cancer Biomarker TPA
}

\author{
Flemming Lund ${ }^{1}$, György Sölétormos ${ }^{1}$, \\ Merete Frejstrup Pedersen ${ }^{1}$ and Per Hyltoft Petersen ${ }^{1,2}$ \\ ${ }^{1}$ Department of Clinical Biochemistry, Hillerød Hospital, University of Copenhagen, \\ ${ }^{2}$ Norwegian Quality Improvement of Primary Care Laboratories (NOKLUS), \\ Section for General Practice, University of Bergen, Bergen, \\ ${ }^{1}$ Denmark \\ ${ }^{2}$ Norway
}

\section{Introduction}

Concentrations of biomarkers for cancers (tumour markers) in plasma vary over time, and the ideal biomarker is a component which reflects the size of the tumour. Optimal interpretation of serial data on biomarkers during monitoring of patients following treatment of malignant disease is therefore vital for early prediction of reappearance of the tumour or metastases. Consequently, an ideal tumour biomarker will signal such reappearance before being detected by other relevant methods. On the other hand any false positive signals which can lead to superfluous investigations and unnecessary anxiety for the patient must be avoided. Because the biomarkers are produced in small amounts and released to plasma during healthy conditions, and because concentrations in plasma vary over time, it is necessary to be able to distinguish between true and false signals when serial measurements after treatment are to be interpreted. Here, different algorithms are proposed in literature, and this chapter deals with validation of some of these algorithms designed for the biomarker TPA (tissue polypeptide antigen) used in follow-up in treated breast tumours. 
In contrast to the common statistics used for comparing two or several groups or some distributions, the purpose with the algorithms for bio-markers is to decide at each sampling and measurement time whether there is a reappearance of the tumour and whether or not there are metastases.

Several algorithms to interpret serial measurements of these markers for monitoring have been proposed and used in clinical trials. The simplest algorithm, used by all kit manufactures and included in their inserts, as also published by Barak et al. (1990), is a cutoff which defines relapse when the marker concentration exceeds this concentration. All algorithms include a cut-off, either directly in the interpretation or indirectly as an algorithm to be used either below or above the cut-off value. Some algorithms are based on two measurements (e.g. a minimum and the latest measured value) and crossing of the cut-off limit, while others include rules for the size of a critical difference of $25 \%$ (Tondini \& Hayes, 1989) or a doubling (Söletormos et al., 1996) or significant change (Söletormos et al., 1996) according to the reference change value (RCV) concept introduced by (Harris \& Yasaka, 1983). An increase of $25 \%$ either below or above the cut-off for both measured concentrations (Dinistrian et al., 1991), and also a doubling or significant change when all measurements are above the cut-off value has been proposed (Söletormos et al., 1996). Others are based on three measurements, where the last measurement is a third, confirmatory test for the increase, and these have also been recommended when crossing the cut-off (Chan et al. 1997; Molina et al., 1995; Nicolini et al., 1991; Söletormos et al., 1996), in addition to algorithms where all measurements are below the cut-off (Bonfrer, 1990) as well as for situations where all measurements are above the cut-off (Bonfrer, 1990; Mughal et al., 1983; Söletormos et al., 1996).

All these algorithms give different signals for the same monitoring data, and a comparison of outcomes in the form of true positive and false positive results based on computer simulations of relevant monitoring situations has been performed (Söletormos et al., 2000b). These illustrate for each algorithm the advantages in terms of time to detection of reappearance, and disadvantages in the form of false positive signals. The basic biological and clinical data for estimated values of within-subject biological variation of serum-TPA $\left(\mathrm{CV}_{\mathrm{B}}\right)$ during steady-state are available (Söletormos et al., 2000a). The rates of exponential increases in serum TPA during tumour growth are based on monitoring data from breast cancer patients (Söletormos et al., 2000a).

It has been demonstrated by Iglesias et al. (2005) that, for monitoring, the benefit of using the RCV (Harris \& Yasaka, 1983) compared to a cut-off depends on the distance between the cut-off and the first measured concentration of the difference between two consecutive measurements to be compared to the RCV. When this distance is small, the probability of crossing the cut-off by the second measurement is higher than the probability of obtaining a significant change between the two measurements. Larger distances speak in favour of the reference change value.

The purpose of this chapter is to demonstrate the influence of the distance between the cutoff and the initial (baseline) concentration for TPA in serum in a simulation study like the paper on the tumour marker CA 15-3 (Petersen et al., 2011). This is done by challenging the different algorithms, where crossing the cut-off is part of the criterion, by computer simulations of various situations of monitoring breast cancer, imitating various exponential increases corresponding to recurrent cancer and a range of values of biological variation in order to validate the algorithms. 


\section{Interpretation of serial TPA concentrations}

\subsection{Materials and methods}

The materials were data and parameters for breast cancer patients obtained from the literature (Söletormos et al., 1996; Söletormos et al., 2000a).

\subsubsection{Cut-off}

The cut-off concentration for TPA during treatment and follow-up of women with breast cancer is $95 \mathrm{U} / \mathrm{L}$, recommended by the manufacture of the TPA kit (AB Sangtec Medical, Bromma, Sweden).

\subsubsection{Steady-state, biological and analytical variation}

The variations during the stable period of monitoring breast cancer patients are considered as steady-state and expressed as within-subject biological variation $\left(\mathrm{CV}_{\mathrm{B}}\right)$ and analytical variation $\left(\mathrm{CV}_{\mathrm{A}}\right)$ according to Sölétormos et al. (2000a). However, the within-subject biological variation, $C V_{B}$, is not homogeneous. Therefore $C_{B}$ for 5 th, 50th and 95th percentile has been used with the analytical variation $\mathrm{CV}_{\mathrm{A}}$ as a constant.

For TPA the 50th percentile for within-subject biological variation, $\mathrm{CV}_{\mathrm{B}} \%$, is $24.5 \%$ and analytical variation, $\mathrm{CV}_{\mathrm{A}} \%$, is $8.4 \%$.

For TPA the 95th percentile of within-subject biological variation, $\mathrm{CV}_{\mathrm{B}} \%$, is $48.9 \%$ and analytical variation, $\mathrm{CV}_{\mathrm{A}} \%$, is $8.4 \%$

For TPA the 5th percentile of within-subject biological variation, $\mathrm{CV}_{\mathrm{B}} \%$, is $8.5 \%$ and analytical variation, $\mathrm{CV}_{\mathrm{A}} \%$, is $8.4 \%$ (Söletormos et al., 2000a).

\subsubsection{Tumour biomarker increase}

The estimated values for the rate of increase $(\lambda)$ in biomarkers after relapse in women with breast cancer are available (Söletormos et al., 2000a). The increase is assumed to be exponential ( $\mathrm{e}^{\lambda \mathrm{t}}$ ) and the $\lambda$-values for the $5 \%, 50 \%$, and $95 \%$ percentiles are $0.0132,0.0346$, and 0.0907, respectively (Söletormos et al., 2000a).

\subsubsection{Algorithms}

Barak et al. $\{1\}$ :

Two consecutive measurements. The first below and the second above cut-off (Barak et al., 1990).

Tondini \& Hayes $\{2\}$ :

At least two measurements. The last measurement is above cut-off and at least $25 \%$ higher than any previous measurement below the cut-off concentration (Tondini \& Hayes, 1989).

Söletormos et al. A $\{3\}$ :

At least two measurements. The last measurement is above cut-off and at least twice (doubling) of any previous measurement below the cut-off (Söletormos et al., 1996). 
Chan et al. $\{4\}$ :

Three consecutive measurements. The last and middle concentrations are both above the cut-off and the first is below the cut-off (Chan et al., 1997).

Söletormos et al. B $\{5\}$ :

At least three measurements. The last concentration is higher than the penultimate concentration and both are above the cut-off. The penultimate concentration is significantly higher than any previous measurement below the cut-off (Söletormos et al., 1996).

Molina et al. $\{6\}$ :

Three consecutive measurements. The first concentration is below twice the cut-off (doubling) and the last two are both above twice the cut-off (doubling) (Molina et al., 1995).

Nicolini et al. $\{7\}$ :

Three consecutive measurements. The first measured concentration is below the cut-off. The middle concentration is above the cut-off and the last measured concentration is $>30 \%$ higher than the middle measured concentration (Nicolini et al., 1991).

\subsubsection{Methods}

The basic principles and methods have been presented previously (Petersen et al., 2011; Söletormos et al., 2000b), and the basic model and the additional calculations of results for the varying start concentrations of TPA between the cut-off and these initial concentrations are described in detail below.

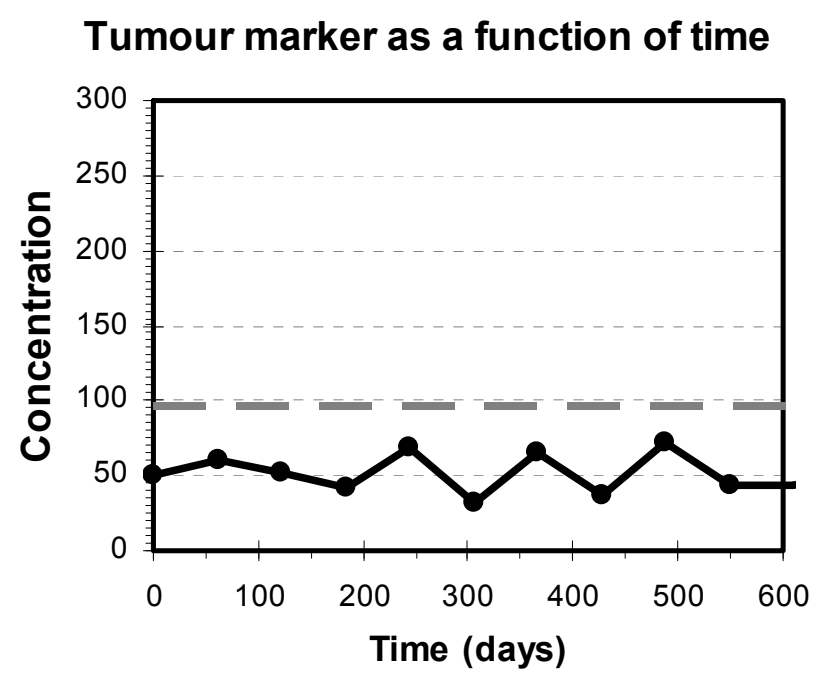

Illustration of simulated data for steady-state concentrations (-•-), with a mean concentration 50 U/L, $\mathrm{CV}_{\mathrm{B}}=24.5 \%$ and $\mathrm{CV}_{\mathrm{A}}=8.5 \%$. Baseline (starting) concentration $50 \mathrm{U} / \mathrm{L}$ and the cut-off concentration, 95 $\mathrm{U} / \mathrm{L},(---)$. Sampling frequency every two months (61 days).

Fig. 1A. Steady-state graph 


\section{Tumour marker as a function of time}

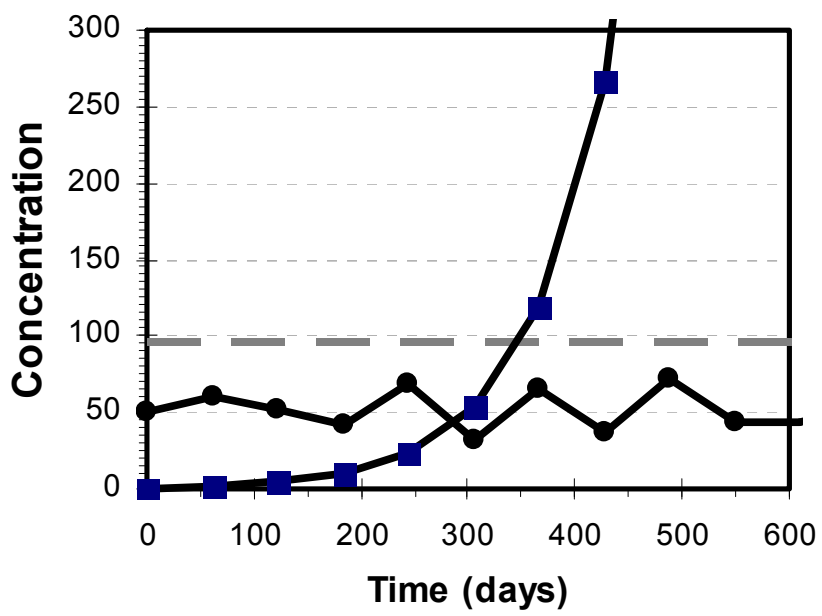

Illustration of simulated data for steady-state concentrations (-•-), with a mean concentration $50 \mathrm{U} / \mathrm{L}$, $\mathrm{CV}_{\mathrm{B}}=24.5 \%$ and $\mathrm{CV}_{\mathrm{A}}=8.5 \%$, and tumours with exponential growth $\lambda=0.0132(-\mathbf{-})$ )), according to $0.95^{*}$ $\mathrm{e}^{\lambda^{*} \mathrm{t}} \mathrm{U} / \mathrm{L}$. Baseline (starting) concentration $50 \mathrm{U} / \mathrm{L}$ and the cut-off concentration, $\left.95 \mathrm{U} / \mathrm{L},(--)^{-}-\right)^{-}$

Sampling frequency every two months (61 days).

Fig. 1B. Steady-state and tumour growth graphs.

\section{Tumour marker as a function of time}

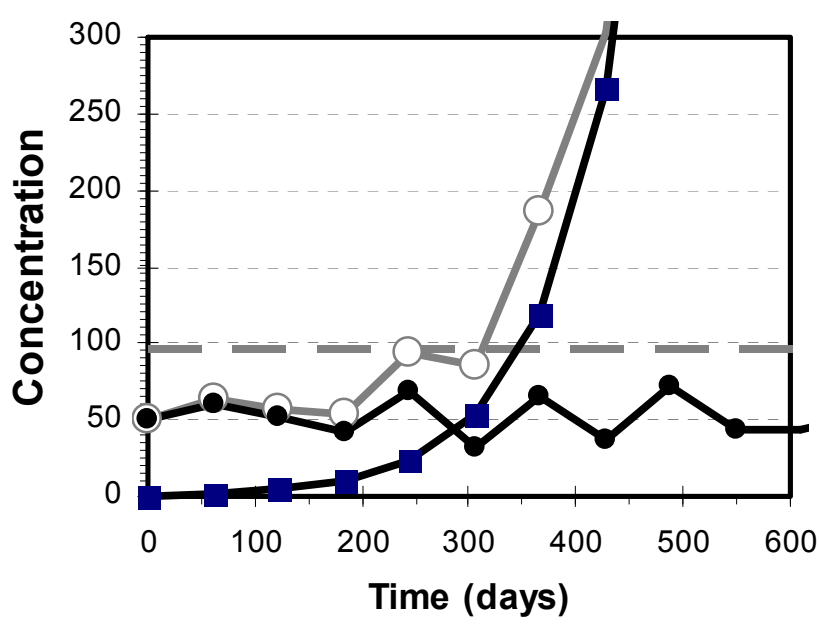

Illustration of simulated data for steady-state concentrations (- $\bullet-)$, with a mean concentration $50 \mathrm{U} / \mathrm{L}$, $\mathrm{CV}_{\mathrm{B}}=24.5 \%$ and $\mathrm{CV}_{\mathrm{A}}=8.5 \%$, and tumour with exponential growth $\left.\lambda=0.0132(-\mathbf{-}-)\right)$, according to $0.95^{*}$ $\mathrm{e}^{\lambda^{*} \mathrm{t}} \mathrm{U} / \mathrm{L}$. Baseline (starting) concentration for the course is $50 \mathrm{U} / \mathrm{L}$ and the cut-off concentration, $95 \mathrm{U} / \mathrm{L}$, (- - - ). Sampling frequency every two months (61 days). The (-o-) graph is the addition result of steadystate concentrations $(-\bullet-)$ plus $0.95^{*} \mathrm{e}^{\lambda^{*} \mathrm{t}} \mathrm{U} / \mathrm{L}$.

Fig. 1C. Steady-state, tumour growth and resulting graphs. 


\section{Tumour marker as a function of time}

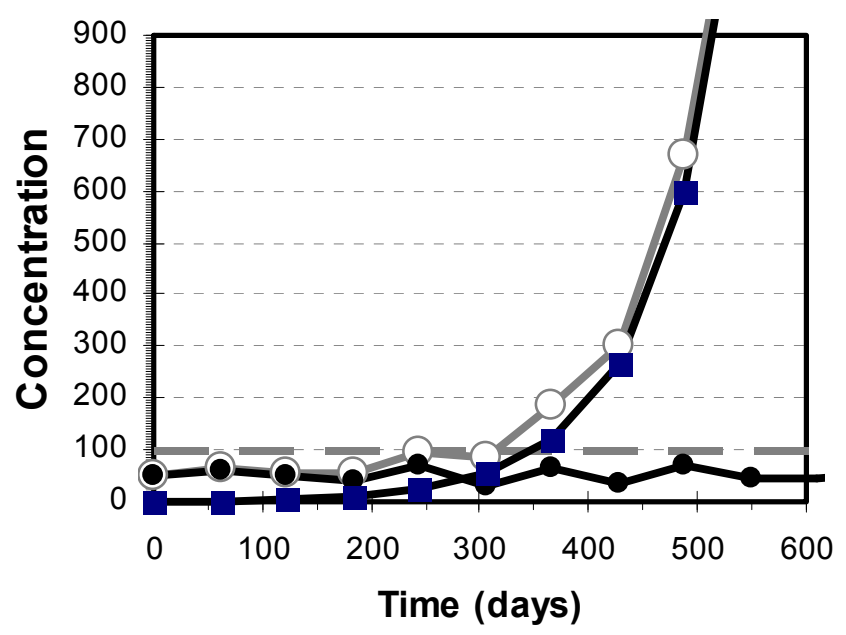

The same as fig. 1C except chanced scale of concentrations U/L. The resulting graph and the exponential graph will in time be nearly indistinguishable, here after approx. 500 days.

Fig. 1D. Steady-state, tumour growth and resulting graphs.

\subsubsection{Basic simulation}

Simulation of concentration data using Microsoft Excel version 2003.

\subsubsection{Steady-state}

For each patient, a series of "concentrations" of biomarker was calculated from simulated data as a function of time 'after treatment'. For each 'sample' during steady-state conditions, the resulting concentration value $\left(\mathbf{c}_{\mathrm{ij}}\right)$ is calculated from a chosen 'steady-state' concentration $\left(\mathbf{c}_{\mathrm{s}-\mathrm{s}}\right)$ with the addition of a random number $\left(\right.$ random $\left._{\mathrm{i}}\right)$ from a Gaussian distribution multiplied by 'the steady-state within-subject biological variation' $\left(\mathrm{CV}_{\mathrm{B}}\right)$, plus a new random number $\left(\right.$ random $\left._{\mathrm{j}}\right)$ from a Gaussian distribution multiplied by the analytical variation $\left(\mathrm{CV}_{\mathrm{A}}\right)$ according to the model (Bliss, 1967):

$$
\mathbf{c}_{\mathrm{ij}}=\mathbf{c}_{\mathrm{s}-\mathrm{s}} *\left[1+\operatorname{random}_{\mathrm{i}} * \mathrm{CV}_{\mathrm{B}} \% / 100+\operatorname{random}_{\mathrm{j}} * \mathrm{CV}_{\mathrm{A}} \% / 100\right]
$$

This is performed for 50 samples in series, numbered from 1 to 50 and each corresponding to a specific day of monitoring when sampling is performed every two months (61 days), and further performed for each patient with new random Gaussian numbers for a total of 1000 surrogate patients. The result is a series of random concentration values with a mean close to the chosen value $\left(\mathrm{c}_{\mathrm{s}-\mathrm{s}}\right)$. Fig. $1 \mathrm{~A}$ illustrates a steady-state situation, where the fluctuations are based on within- subject biological variation $\left(\mathrm{CV}_{\mathrm{B}}\right)$ plus analytical imprecision variation $\left(\mathrm{CV}_{\mathrm{A}}\right)$. 


\subsubsection{Tumour growth}

Based on data from Sölétormos et al. $(1997,2000 a)$, increases in biomarkers are shown to be associated with progression of disease and it is found that the concentrations of biomarkers have an exponential relation with time. However, the rate of tumour growth can vary considerably. The rate of increase is expressed as $\lambda$ in the exponential function as a factor in the exponent in $\mathrm{e}^{\lambda_{\mathrm{t}}}$ or as $\exp (\lambda \mathrm{t})$. The rate of increase $\lambda$ (also called slope) was calculated for TPA in patients Sölétormos et al. (2000a) and found as $5^{\text {th }}$ percentile $(\lambda=0.0132)$, as $50^{\text {th }}$ percentile $(\lambda=0.0346)$ and as $95^{\text {th }}$ percentile $(\lambda=0.0907)$. Therefore, in the simulation model tumour growth is described as an exponential increase in the biomarker TPA. The start concentration $(t=0)$ of the biomarker originating from the tumour is arbitrarily selected as an amount corresponding to a concentration 100 times lower than the cut-off concentration $(0.95 \mathrm{U} / \mathrm{L})$. The resulting function of the TPA from the tumour is then expressed as $0.95 \mathrm{e}^{\lambda_{\mathrm{t}}}$ or as $0.95 \exp (\lambda t)$. See Fig 1B as an example of an exponential tumour growth where $\lambda=0.0132$.

\section{Tumour marker as a function of time}

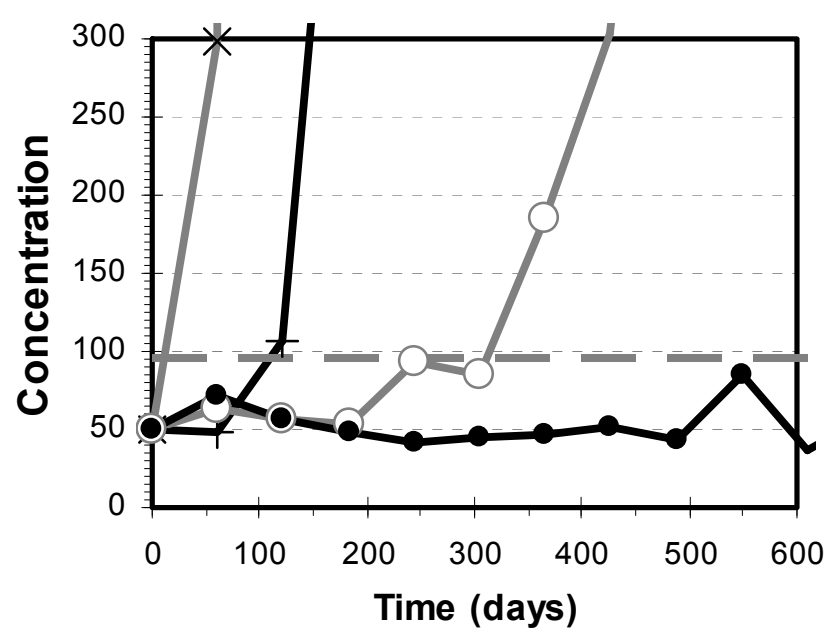

Illustration of simulated data for steady-state concentrations (-•-), with a mean concentration $50 \mathrm{U} / \mathrm{L}$ and $\mathrm{CV}_{\mathrm{B}}=24.5 \%$ and $\mathrm{CV}_{\mathrm{A}}=8.5 \%$, and tumours with exponential growth $\lambda=0.0132(-0-), \lambda=0.0346(-+-)$ , and $\lambda=0.0907\left(-x_{-}\right)$according to $0.95^{*} \mathrm{e}^{\lambda \star_{t}} \mathrm{U} / \mathrm{L}$. Baseline (starting) concentration for the four courses is $50 \mathrm{U} / \mathrm{L}$ and the cut-off concentration, $95 \mathrm{U} / \mathrm{L},(---)$. Sampling frequency every two months (61 days).

Fig. 2. Different rates of tumour growth increase.

As a resulting graph the tumour concentration is now added to the steady-state concentration (steady-state concentration + initial tumour $(0.95 \mathrm{U} / \mathrm{L}))$. An example is illustrated in Fig 1C. At first, the resulting graph has nearly the same concentration as the steady-state graph, but after some time TPA products from the tumour take over as the dominating contributor. Thereafter steady-state concentrations might be neglected as the resulting graph will be close to the exponential tumour graph (see Fig 1D). This process is repeated until a total of 1000 'patient pathways' are evaluated using the same parameters. In Fig 2 is illustrated an 
example of the resulting graphs from 3 different rates of tumour increases (slopes $=\lambda$ ) and a steady-state situation where $\lambda=0$. When $\lambda$ is high, the biomarker will increase fast and correspondingly the smaller slopes will show later increases.

\subsubsection{Testing the algorithms by application to the simulated data}

For each 'patient', the investigated algorithm is applied in sequential order and when a sample is positive according to the algorithm, it is recorded as a positive biomarker signal (POS). Summing up all the 1000 simulated 'patients', the percentage that are positive in each sample number (same days) is calculated, resulting in a growing graph in a plot of percentage biomarker positive as a function of sample number or day/months. This is illustrated in figure 3 for four different values of $\lambda$, including zero (= steady-state).

The slopes become steeper for increasing $\lambda$-values, which means that the detection of tumour growth is earlier for fast growing tumours, as expected. The POS signals for the steady-state situation $(\lambda=0.000)$ represent false positive signals (in the example in Fig. 3 it is $0 \%$ after 600 days, approximately 20 months). In steady-state, POS signals will be recorded as false positive because no tumour growth is simulated, and therefore the POS signals cannot be considered true positives. For the three other graphs, the POS signals are recorded as true positives because an exponential tumour growth is simulated. In validation of the different algorithms, the time for $100 \%$ POS is important, but from a theoretical point of view, the most interesting variables are the lowest $\square$-values (0.000 and 0.0123), which are the most difficult to distinguish - and at the same time very important for follow-up of tumourproducing biomarkers after surgery, chemotherapy etc.

\section{Percentage of POS as a function of time}

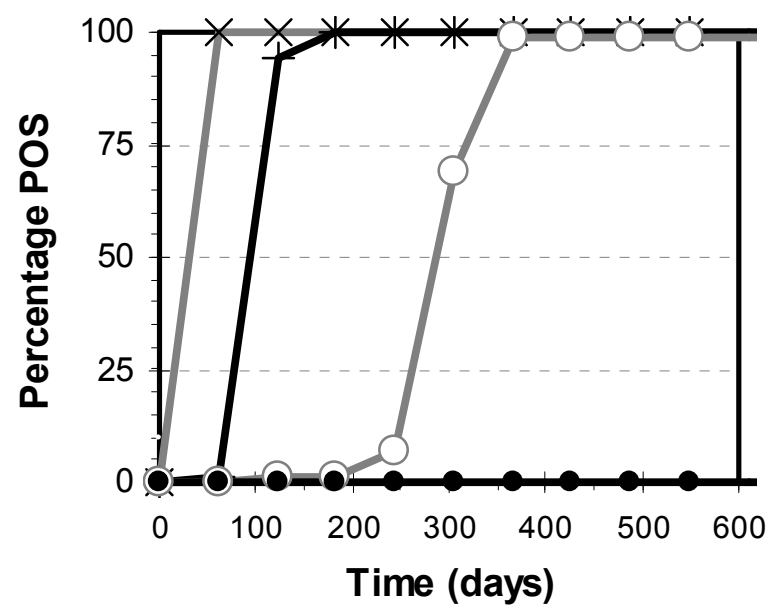

Illustration of the algorithm from Barak et al. $\{1\}$ considered POS when the concentration first exceeds the cut-off $(\mathrm{TPA}=95 \mathrm{U} / \mathrm{L})$. Percentage POS as a function of time for four different exponential increases with $\lambda=0.0132(-\circ-), \lambda=0.0346(-+-)$, and $\lambda=0.0907(-\mathrm{x}-)$ according to $0.95^{*} \mathrm{e}^{\lambda *_{t}} \mathrm{U} / \mathrm{L}$. The steady-state simulation is represented by $\lambda=0.0000(-\bullet-)$.

Fig. 3. Percentage positive patients (POS) as a function of time. 


\subsubsection{Varying steady-state and start (baseline) concentrations}

For each algorithm, a number of steady-state and start concentrations are used $(2.38,4.75$, 9.5, 14.3, 19.0, 23.8, 28.5, 38.0, 47.5, 57.0, 66.5, 76.0, 85.5, and 95.0 U/L) where the concentration in the first 'sample' is fixed at $0.1 \%$ below the stated concentration in order to ensure that at least one sample from each 'patient' is below the cut-off threshold. The percentage of positives at a certain time/sample is illustrated as a function of the starting concentration for each algorithm (see e.g. Fig 4).

\subsubsection{Biological variation of tumour growth}

As defined in the tumour growth situation, the exponential function is added to the steadystate including a biological variation $\mathrm{CV}_{\mathrm{B}}$. This exponential function can further be varied by multiplying the concentration due to the exponential function by a random factor times 0.25 , which corresponds to an extra biological variation in tumour growth of $25 \%$.

As previously defined, the tumour growth is expressed as an exponential function: $0.95^{*} \mathrm{e}^{\lambda t}$, where $\lambda$ is the slope and $t$ is the time (days or months). The $25 \%$ extra biological variation within the tumour growth is then expressed with:

$$
\left(1+\operatorname{random}_{\mathrm{k}}^{*} 0.25\right)^{*} 0.95^{*} \mathrm{e}^{\lambda \mathrm{t}},
$$

where random $_{\mathrm{k}}$ is a new random number from a Gaussian distribution, and the start concentration of tumour growth is still expressed by the factor 0.95 , when $t=0$, i.e. $1 \%$ of cut-off concentration.

\subsection{Results}

Results for each algorithm are presented with illustrations of the characteristics for each algorithm.

\subsubsection{Algorithm \{1\} Barak et al.}

Two consecutive measurements. The first below and the second above the cut-off (Barak et al., 1990).

In Fig. 4 , the fastest tumour growth $(\lambda=0.0907)$ is $100 \%$ percentages positive (POS) after two months for all start concentrations (sample 2), whereas the remaining graphs have almost the same development, with POS increasing from $0 \%$ at approximately $57 \mathrm{U} / \mathrm{L}$ to approximately $50 \%$ POS at $95 \mathrm{U} / \mathrm{L}$. After six months (sample 4), the next lower slope $(\lambda=$ $0.0346)$ reaching $100 \%$ POS for all start concentrations, whereas the lowest slope $(\lambda=0.0132)$ and steady-state $(\lambda=0.0000)$ slowly increase to approximately $85 \%$ POS near the cut-off of 95 U/L. At ten months (sample 6), the slowest tumour growth has separated from the steadystate concentrations, increasing from 0 to $100 \%$ POS for starting concentrations between 30 and $70 \mathrm{U} / \mathrm{L}$, and false positive (FP) is still zero up to approximately $57 \mathrm{U} / \mathrm{L}$, but has increased to $97 \%$ at $95 \mathrm{U} / \mathrm{L}$.

It is clear from Fig. 4 that true positive (TP) graphs increase with increasing starting concentrations, whereas FP graphs are zero for the low starting concentrations and increase over time for starting concentrations above $57 \mathrm{U} / \mathrm{L}$. 


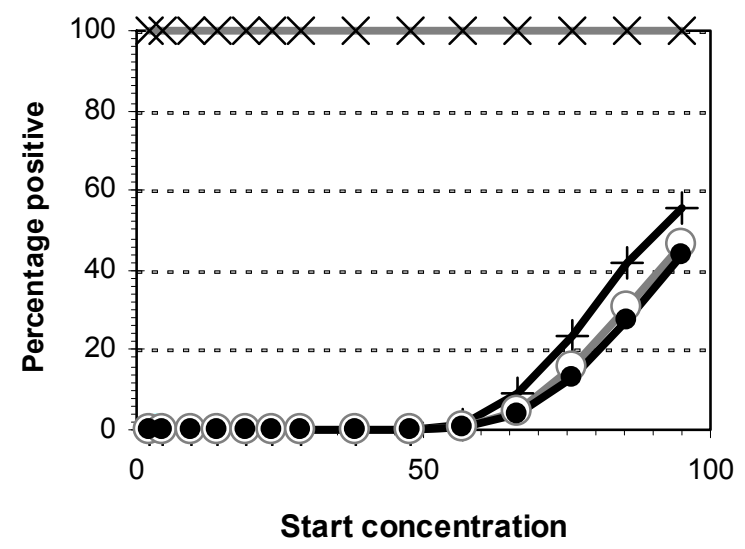

Algorithm:

Barak

Sample 2

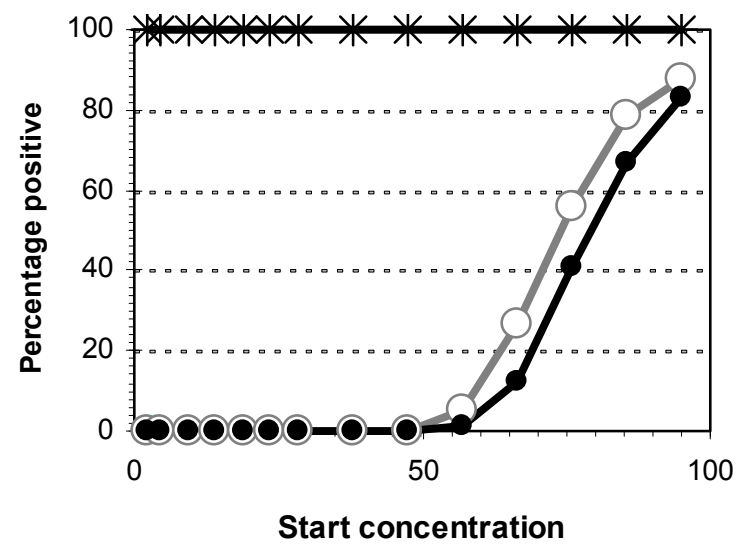

Algorithm:

Barak

Sample 4

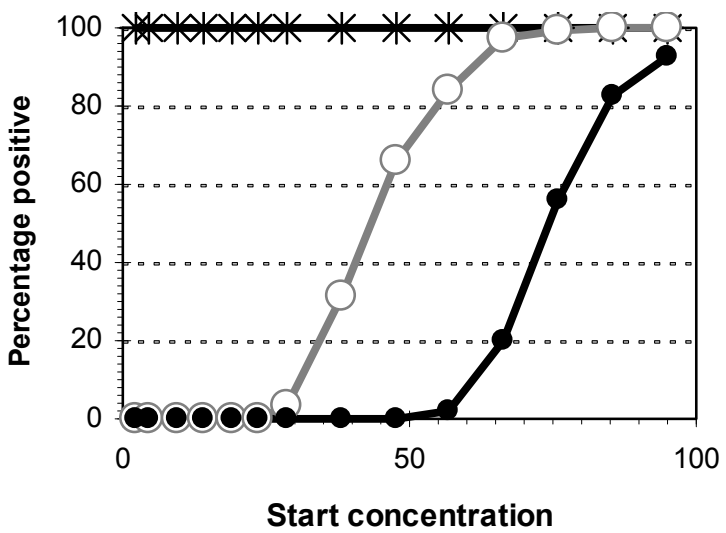

\section{Algorithm:}

Barak

Sample 6

Percentage positive (POS) as a function of starting concentration (TPA U/L) for algorithm $\{1\}$ Barak et al. after 2 months (sample 2), 6 months (sample 4) and 10 months (sample 6). Same slope symbols as in Fig. 2.

Fig. 4. Percentages positive signals at three different times. 
With the only criterion as crossing the cut-off, the algorithm $\{1\}$ from Barak et al. is very simple. In this way the time for progression detection is short - however the percentages of FP are unacceptably high - especially with start concentrations near cut-off - i.e. from approx $57 \mathrm{U} / \mathrm{L}$ to cut-off (95 U/L). After 1 year the FP is $98 \%$ near the cut-off.

In comparison with the other algorithms, which all have more restrictive criteria for recording a positive signal (POS) as in progression of tumour growth, the percentage of FP results decreases. Table 1 lists FP after one and two years, and the algorithm Barak et al. $\{1\}$ has the highest FP (i.e. 98\%) rate in 'patients'. However, if the start concentration is below 57 U/L, the algorithm Barak et al. $\{1\}$ has only few percentages FP (i.e. $3 \%$ ) and at the same time the fastest detection time for progression. Only Tondini \& Hayes $\{2\}$ has comparable "good" POS results for TPA.

\subsubsection{Algorithm $\{2\}$ Tondini \& Hayes}

Two consecutive measurements. The last measurement is above the cut-off and at least $25 \%$ higher than any previous concentration below the cut-off value (Tondin \& Hayes, 1989).

The only difference between algorithm Barak et al. $\{1\}$ and algorithm Tondini \& Hayes $\{2\}$ is that, in the latter algorithm, the criterion is $25 \%$ higher concentration above cut-off compared to the lowest value below cut-off. Many (simulated) patients will be recorded similarly as algorithm Barak et al. $\{1\}$ - especially with low start concentration. Therefore, the performances of these two algorithms are comparable. Algorithm Tondini \& Hayes $\{2\}$ shows only moderately lower percentages of positives (POS) for the lower tumour growths and the steady-state situation at 6 months, i.e. also slightly lower FP between 55 and $95 \mathrm{U} / \mathrm{L}$ during the first half of the year (compare Fig. 4 and Fig. 5 at sample 4).

Although there are a few more restrictions in algorithm Tondini \& Hayes $\{2\}$, the detection time for TP patients is practically the same - however, the percentage of FP is still unacceptable with start concentrations near cut-off.

\subsubsection{Algorithm $\{3\}$ Sölétormos et al. A}

At least two measurements. The last measurement is above cut-off and at least $100 \%$ higher than any previous measurement below the cut-off (doubling) (Söletormos et al., 1996).

This algorithm is comparable to the algorithm Tondini \& Hayes $\{2\}$. The only difference is that the increase is not $25 \%$ but $100 \%$ for the last concentration over cut-off. In other words the three first algorithms are very similar.

The slightly more restrictive criterion with algorithm Söletormos et al. A $\{3\}$ results in much lower FP signals with start concentrations near cut-off (see Fig. 5). For example the percentages of FP signals are reduced from $98 \%$ by algorithm Barak et al. $\{1\}$ to $32 \%$ by algorithm Söletormos et al. A $\{3\}$ after 1 year just below 95 U/L (cut-off) (see Table 1). However, after 6 months it is not possible to distinguish between the slowest tumour growth and healthy steady-state patients (see Fig. 5). Comparison of the algorithm from Söletormos et al. A $\{3\}$ with Barak et al. $\{1\}$ and Tondini \& Hayes $\{2\}$ shows nearly the same results with low start concentrations (below $57 \mathrm{U} / \mathrm{L}$ ) where all three algorithms have only few FP signals. 


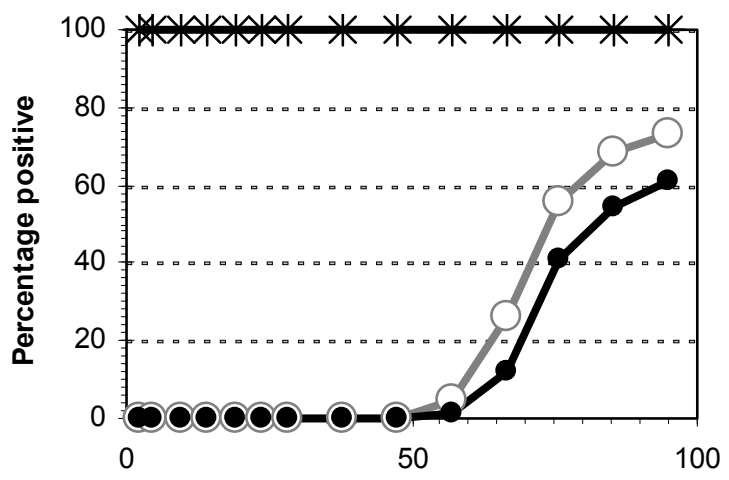

Algorithm:

Tondini

Sample 4

Start concentration

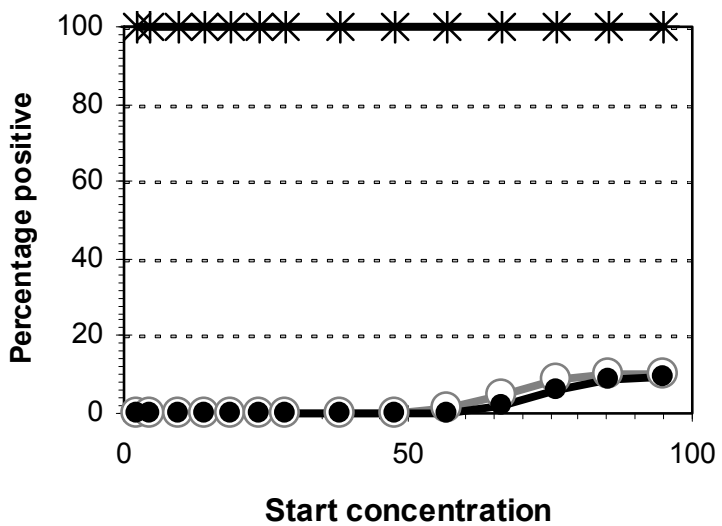

Algorithm:

Sölétormos A

Sample 4

Comparison of the algorithms of algorithm $\{2\}$ Tondini \& Hayes, and algorithm $\{3\}$ Söletormos et al. A at 6 months (sample 4). Percentage positive (POS) as a function of starting concentration as for Fig. 3. The only difference between the two algorithms is the size of increase after crossing the cut-off, i.e. $25 \%$ and $100 \%$, respectively. For symbols see Fig. 3.

Fig. 5. Comparison of two different algorithms.

All three algorithms have also the same tumour detection time - except Söletormos et al. A $\{3\}$ which has extended the time by two months for the slowest tumour growth (see Table 1).

The next four algorithms presented here - all have a characteristic in common - they all need at least three measurements. As a consequence, the earliest detection time for tumour progression is 4 months. In Table 1, these algorithms are marked with a footnote: 'Three sample points are needed'.

\subsubsection{Algorithm \{4\} Chan et al.}

Three consecutive measurements. The last and penultimate concentrations are both above the cut-off, and the first measured concentration is below cut-off (Chan et al., 1997). 
The algorithm Chan et al. $\{4\}$ appears similar to algorithm Barak et al. $\{1\}$ with the addition of a confirmation of crossing the cut-off. When the graph is crossing the cut-off ( $95 \mathrm{U} / \mathrm{L})$ - the next sample should also be above cut-off. In this way the percentage FP signals may be reduced - from $98 \%$ FP by algorithm Barak et al. $\{1\}$ to $64 \%$ FP by algorithm Chan et al. $\{4\}$ after 1 year below $95 \mathrm{U} / \mathrm{L}$. As a consequence - the detection times are correspondingly 2 months later for all 3 slopes.

\begin{tabular}{|c|c|c|c|c|c|c|c|}
\hline Algorithm & $\begin{array}{l}\text { Slope } \\
0.0907: \\
100 \% \text { at } \\
\text { time }\end{array}$ & $\begin{array}{l}\text { Slope } \\
0.0346: \\
100 \% \text { at } \\
\text { time }\end{array}$ & $\begin{array}{l}\text { Slope } \\
0.0123 \text { : } \\
100 \% \text { at } \\
\text { time }\end{array}$ & $\begin{array}{l}\text { False } \\
\text { positive } \\
\text { below } \\
95 \mathrm{U} / \mathrm{L} \\
\text { at } 1 \text { year }\end{array}$ & $\begin{array}{l}\text { False } \\
\text { positive } \\
\text { below } 95 \\
\text { U/L at } 2 \\
\text { years }\end{array}$ & $\begin{array}{l}\text { False } \\
\text { positive } \\
\text { below } 57 \\
\text { U/L at } 1 \\
\text { year }\end{array}$ & $\begin{array}{l}\text { False } \\
\text { positive } \\
\text { below } 57 \\
\text { U/L at } 2 \\
\text { years }\end{array}$ \\
\hline $\begin{array}{l}\text { Barak } \\
\text { et al. }\{1\}\end{array}$ & 2 months & 6 months & 12 months & $98 \%$ & $100 \%$ & $3 \%$ & $4 \%$ \\
\hline $\begin{array}{l}\text { Tondini } \\
\text { and } \\
\text { Hayes }\{2\}\end{array}$ & 2 months & 6 months & 12 months & $91 \%$ & $100 \%$ & $3 \%$ & $4 \%$ \\
\hline $\begin{array}{l}\text { Söletormos } \\
\text { et al. A }\{3\}\end{array}$ & 2 months & 6 months & 14 months & $32 \%$ & $70 \%$ & $2 \%$ & $3 \%$ \\
\hline $\begin{array}{l}\text { Chan } \\
\text { et al. }\{4\}\end{array}$ & [4 months $]^{1}$ & 8 months & 14 months & $64 \%$ & $91 \%$ & $0 \%$ & $0 \%$ \\
\hline $\begin{array}{l}\text { Söletormos } \\
\text { et al. B \{5\} }\end{array}$ & {$[4 \text { months }]^{1}$} & 8 months & 16 months & $6 \%$ & $24 \%$ & $0 \%$ & $0 \%$ \\
\hline $\begin{array}{l}\text { Molina } \\
\text { et al. }\{6\}\end{array}$ & [4 months $]^{1}$ & 8 months & 16 months & $0 \%$ & $0 \%$ & $0 \%$ & $0 \%$ \\
\hline $\begin{array}{l}\text { Nicolini } \\
\text { et al. }\{7\}\end{array}$ & [4 months $]^{1}$ & [8 months] & $2[14$ months & $6 \%$ & $10 \%$ & $0 \%$ & $0 \%$ \\
\hline
\end{tabular}

${ }^{1}$ Three sample points are needed for the algorithm. ${ }^{2}$ Only at start concentrations below $57 \mathrm{U} / \mathrm{L}$ obtain $100 \%$. ${ }^{3}$ Only at start concentrations below $28 \mathrm{U} / \mathrm{L}$ obtain $100 \%$.

Times for detection of $100 \%$ tumour progression using the different algorithms are listed for three slopes. Percentages of false positive results after 1 and 2 years with TPA start concentrations below 95 $\mathrm{U} / \mathrm{L}$ and $57 \mathrm{U} / \mathrm{L}$ for each algorithm are also listed. All results are generated from 1000 computer simulations.

Table 1. Performance results from seven algorithms.

\subsubsection{Algorithm \{5\} Sölétormos et al. B}

At least three measurements. The last measured concentration is higher than the penultimate concentration, both above the cut-off, and higher than the third to last measured concentration. The penultimate concentration is significantly higher than any previous measurements below the cut-off (Söletormos et al., 1996).

In a comparison of algorithm Chan et al. $\{4\}$ with algorithm Söletormos et al. B $\{5\}$, the latter algorithm is much more restrictive in recording positive signals (POS). The last measurement demands an increase compared to the penultimate value - and this 
penultimate value has to have a significant increase compared to earlier measurements (see below). The more restrictive criteria are shown to give much lower FP signals - even after two years, the percentages of FP results are $24 \%$ compared to $91 \%$ at algorithm Chan et al. $\{4\}$ below $95 \mathrm{U} / \mathrm{L}$. Again more restrictive criteria have a 'cost' in regard to detection time here at the slowest slope, which is extended by two months at algorithm Söletormos et al. B $\{5\}$. On the other hand these algorithms show only $0 \% \mathrm{FP}$ results at low start concentrations, i.e. below $57 \mathrm{U} / \mathrm{L}$.

The significant increase, or reference change value (RCV), was introduced by Harris and Yasaka (1983) in order to detect a significant change in consecutive measurements, and was defined as $\mathrm{RCV}=1.96^{*} 2^{1 / 2 *} \mathrm{CV}_{\mathrm{B}}$, where the 1.96 is the standard deviation from a Gaussian distribution corresponding to a two-tailed probability of $5 \%$, and $2^{1 / 2}$ relates to the variation of differences $\mathrm{CV}_{\text {Difference }}=\left(\mathrm{CV}_{\mathrm{B}}{ }^{2}+\mathrm{CV}_{\mathrm{B}}\right)^{1 / 2}$ or the $\mathrm{CV}_{\mathrm{B}}{ }^{2}$ can be substituted by the combination of biological and analytical variation. The calculation in the computer system is the test of the difference between two consecutive measurements (as a percentage) in regard to the RCV.

\subsubsection{Algorithm \{6\} Molina et al.}

Three consecutive measurements. The first is below cut-off and the next two measurements are both over double the cut-off value (Molina et al., 1995).

This algorithm Molina et al. $\{6\}$ is comparable with algorithm Chan et al. $\{4\}$ - a confirmation of crossing cut-off with an extra sample - but at algorithm Molina et al. $\{6\}$, there is a doubling of the cut-off (to $190 \mathrm{U} / \mathrm{L}$ ).

This very restrictive criterion results in $0 \%$ FP results - even also near cut-off. This algorithm has the lowest number of FP, i.e. $0 \%$, in comparison to all the other algorithms. And, again, strict restrictions inhibit the ability to detect early tumour progression - algorithm Molina et al. $\{6\}$ has the longest detection time shared with algorithm Söletormos et al.B $\{5\}$ and algorithm Nicolini et al $\{7\}$.

\subsubsection{Algorithm \{7\} Nicolini et al.}

Three consecutive measurements. The first measured concentration is below the cut-off, the middle measured concentration is above the cut-off and the last is more than $30 \%$ higher than the middle value (7).

The algorithm Nicolini et al. $\{7\}$ can also be compared with algorithm Chan et al. A crossing of cut-off has to be confirmed by a new sample - but this new sample has to be $30 \%$ higher compared to the second measurement over cut-off.

This $30 \%$ higher concentration for the two last measurements is difficult to fulfil for the two slowest tumour growths for starting concentrations just below the cut-off. The exponential function simulated from tumour growth has to have some time before an increase effect is observed in the results. As a consequence, the graphs decrease with increasing starting concentrations without the possibility of giving a positive signal (POS), because when crossing the cut-off too slowly, there will never be a POS signal. This is illustrated in Fig. 6 where the graphs for sample 10 and sample 13 are almost identical. 


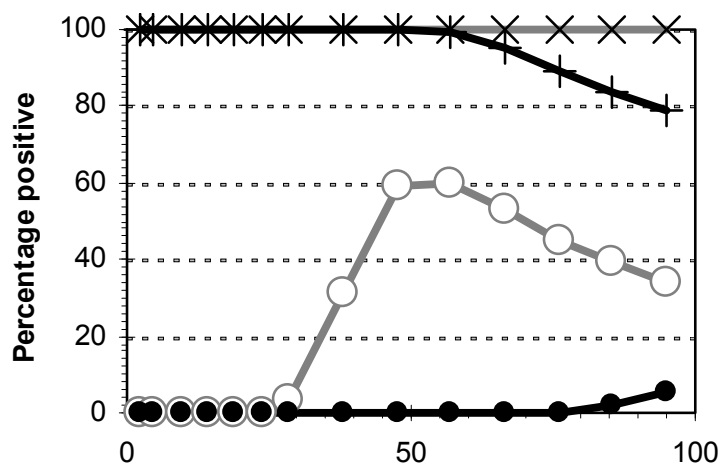

\section{Algorithm:}

Nicolini

\section{Sample 7}

Start concentration

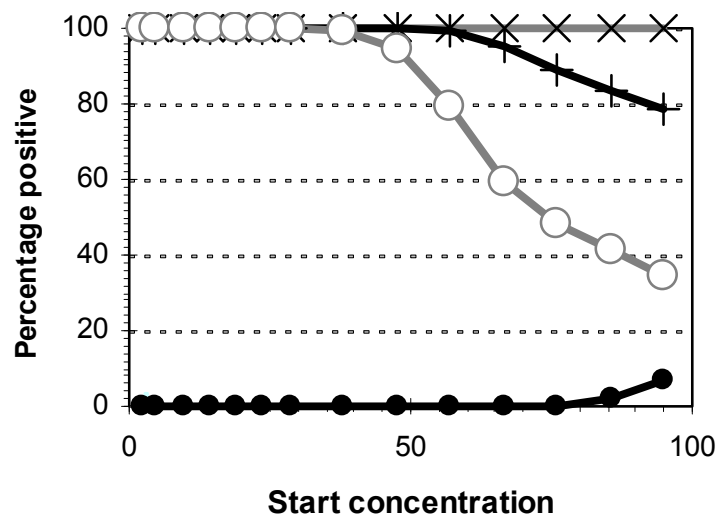

\section{Algorithm:}

Nicolini

Sample 10

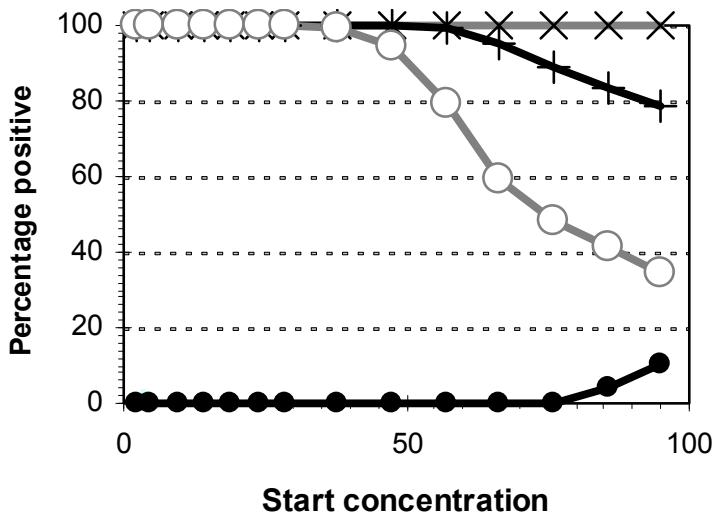

Algorithm:

Nicolini

Sample 13

Percentage positive (POS) as a function of starting concentration for algorithm $\{7\}$ Nicolini et al. after 1 year (sample 7), after 18 months (sample 10), and after two years (sample 13). After sample 8 (14 months) the figures will "freeze" and be identical for the three tumour slopes.

Fig. 6. Results from Algorithm $\{7\}$ Nicolini et al. at different times 
It has to be underlined that, in this way, the algorithm Nicolini et al. $\{7\}$ will never achieve $100 \%$ POS with start concentrations near cut-off. The 100\% POS will only be fulfilled at start concentrations below $28 \mathrm{U} / \mathrm{L}$, for the two slowest slopes (see footnotes in Table 1)

\subsubsection{Overall results}

The characteristics for the seven algorithms are summarised in Table 1 with the time for $100 \%$ true positive results (TP) for each slope of tumour growth, and with percentage false positive (FP) at two years for both start concentrations of $57 \mathrm{U} / \mathrm{L}$ and $95 \mathrm{U} / \mathrm{L}$ (cut-off).

The two first algorithms (Barak et al. $\{1\}$ and Tondini \& Hayes $\{2\}$ ) in Table 1 show the fastest time to detect $100 \%$ positive signals in patients for each of the investigated three slopes. However, these algorithms also show the highest percentage of false positive (FP) signals, both after 1 and 2 years. All the other algorithms also show FP results of lower and varying percentages - except algorithm Molina et al. \{6\} with zero FP. The algorithm Molina et al. $\{6\}$ on the other hand also needs the longest time for $100 \%$ positive results shared with algorithm Söletormos et al. B $\{5\}$. The algorithm Nicolini et al. $\{7\}$ has partly the same long time, but only at start concentrations below $57 \mathrm{U} / \mathrm{L}$ and below $28 \mathrm{U} / \mathrm{L}$ for the slopes 0.0346 and 0.0132 , respectively. Above these start concentrations, the algorithm Nicolini et al. $\{7\}$ will never obtain $100 \%$ positive results (see also Fig 6). In other words after 14 months the two slowest slopes will "freeze" and have the same results. Only FP percentages will increase slowly.

Overall, all the algorithms are comparable when the start concentrations are below $57 \mathrm{U} / 1$ with only few FP results for the algorithms from Barak et al. $\{1\}$, Tondini \& Hayes $\{2\}$ and Söletormos et al. A $\{3\}$. The other algorithms are even better as regards the percentage of FP results. However, they need longer time for detection of tumour progression.

In the clinical situation, when the TPA start concentration is below $57 \mathrm{U} / \mathrm{L}$, it should be recommended to use the algorithm Barak et al. $\{1\}$ in order to obtain an early detection of tumour progression. However, when the TPA start concentration is above $57 \mathrm{U} / \mathrm{L}$ and up to just below $95 \mathrm{U} / \mathrm{L}$, it should be recommended to use the algorithm Molina et al. \{6\}even with a longer detection of tumour progression - in order to avoid any false positive signals.

In a clinical situation using the Nicolini et al. $\{7\}$ algorithm, several patients with slow tumour growth and with high biomarker (TPA) start concentration near cut-off will never be recorded as positive tumour patients - hopefully treatment action will be taken based on high concentrations or other clinical signals.

In this investigation the performances of the algorithms have been studied using results from the biomarker TPA. The same procedure has been used on the same algorithms with results from the biomarker CA 15-3 (Petersen et al., 2011). The results from these two investigations are very similar. The properties from the algorithms on detection time of progression, the percentages of false positive patients (FP), the dependence on start concentration both near cut-off and approx half cut-off - all the overall characteristic results and figures from each algorithm were relatively identical using different biomarkers, i.e. TPA and CA 15-3. 
These results indicate that the relative performance of the investigated algorithms for early detection of tumour progression and avoiding FP results - seems to be independent of the biomarker in the present model and set-up.

It must be underlined that this statement may only be valid based on general considerations. For example biomarkers with relative low steady-state variation combined with high rates of tumour increase may change some of the algorithm performances according to the detection time of progression and percentage of FP signals. In this situation the performance from algorithm Nicolini et al. $\{7\}$ could be better, because start concentration near cut-off may achieve $100 \%$ TP signals within an acceptable timeframe compared with a never ending timeframe in this TPA investigation. Nevertheless, the relative information from the algorithms on performance will still stand. In other words - the best ability to detect tumour progression will often be obtained by using the algorithm from Barak et al. $\{1\}$ and the best ability to get low FP signals will often be obtained by using the algorithm from Molina et al. $\{6\}$ - and this is noteworthy: independent of the biomarker.

\subsubsection{Performance of the algorithms with impact from extreme values of within- subject biological variation $\left(\mathrm{CV}_{\mathrm{B}}\right)$}

An important assumption for calculation of within-subject biological variation as the square root of the mean of the variances from the individual coefficients of variation of reference individuals in projects on biological variation is that these variations are distributed homogeneously. If there is variance homogeneity, this pooled coefficient of variance represents all individuals of the reference group and it is correct to use this pooled $\mathrm{CV}_{\mathrm{B}}$ in the simulations as a factor for the random Gaussian values. This assumption, however, is not fulfilled for TPA (Sölétormos et al. 2000a), where the range of coefficients of variation goes from $8.5 \%$ and $48.9 \%$ and represents individual $\mathrm{CV}_{\mathrm{B}}$-values, from which the extreme values used for the challenging of algorithms in the simulations are selected.

The results in Table 1 are based on $\mathrm{CV}_{\mathrm{B}}=24.5 \%$ (within-subject biological variation). This value is based on a $50^{\text {th }}$ percentile from an investigation on 127 patients (Söletormos et al., $2000 \mathrm{~b}$ ). Due to the lack of variance homogeneity, we have also investigated the impact on the results from the algorithms based on a $95^{\text {th }}$ percentile where $C V_{B}=48.9 \%$.

The results for $\mathrm{CV}_{\mathrm{B}}=48.9 \%$ are listed in Table 2 where it can be seen that the detection times for tumour progression are practically the same as for the $50^{\text {th }}$ percentile of biological variation. Only algorithm Söletormos et al. B $\{5\}$ shows a 2 months later detection time for a slope of 0.0123 . Nearly all algorithms show an increased percentage of false positive signals (the four first algorithms are already close to $100 \%$ for $\mathrm{CV}_{\mathrm{B},}=24.5 \%$ for the highest start concentrations) with the higher biological variation $\mathrm{CV}_{\mathrm{B}}$. Only the algorithm Molina et al. $\{6\}$ maintains $0 \%$ FP results in situations with high biological variations. It should also be noted that the algorithm results from Söletormos et al. A $\{3\}$ and Söletormos et al. B $\{5\}$ both markedly increase the number of FP results, when the biological variation, $C_{B}$, is high and the start concentration is below cut-off. For Söletormos et al. B $\{5\}$ this is partly due to the algorithm, where the significant change in the criterion is based on the $50^{\text {th }}$ percentile of biological variation $C_{B}=24.5 \%$ whereas the simulation is based on the much higher extreme $\mathrm{CV}_{\mathrm{B}}=48.9 \%$. Consequently the use of significant change in the algorithm makes it sensitive to lack of variance homogeneity. 


\begin{tabular}{|c|c|c|c|c|c|c|c|}
\hline Algorithm & $\begin{array}{l}\text { Slope 0.0907: } \\
100 \% \text { at time }\end{array}$ & $\begin{array}{l}\text { Slope } 0.0346: \\
100 \% \text { at time }\end{array}$ & $\begin{array}{l}\text { Slope } 0.0123 \text { : } \\
100 \% \text { at time }\end{array}$ & $\begin{array}{l}\text { False- } \\
\text { positive } \\
\text { below } \\
95 \mathrm{U} / \mathrm{L} \\
\text { at } 1 \text { year }\end{array}$ & $\begin{array}{l}\text { False } \\
\text { positive } \\
\text { below } 95 \\
\text { U/L at } 2 \\
\text { years }\end{array}$ & $\begin{array}{l}\text { False } \\
\text { positive } \\
\text { below } 57 \\
\text { U/L at } 1 \\
\text { year }\end{array}$ & $\begin{array}{l}\text { False } \\
\text { positive } \\
\text { below } 57 \\
\text { U/L at } 2 \\
\text { years }\end{array}$ \\
\hline $\begin{array}{l}\text { Barak } \\
\text { et al. }\{1\}\end{array}$ & $\begin{array}{l}2 \text { months } \\
\text { (2 months) }\end{array}$ & $\begin{array}{l}6 \text { months } \\
\text { (6 months) }\end{array}$ & $\begin{array}{l}12 \text { months } \\
\text { (12 months) }\end{array}$ & $\begin{array}{c}98 \% \\
(98 \%)\end{array}$ & $\begin{array}{c}100 \% \\
(100 \%)\end{array}$ & $\begin{array}{l}45 \% \\
(3 \%)\end{array}$ & $\begin{array}{l}70 \% \\
(4 \%)\end{array}$ \\
\hline $\begin{array}{l}\text { Tondini and } \\
\text { Hayes }\{2\}\end{array}$ & $\begin{array}{l}2 \text { months } \\
\text { (2 months) }\end{array}$ & $\begin{array}{l}6 \text { months } \\
\text { (6 months) }\end{array}$ & $\begin{array}{l}12 \text { months } \\
\text { (12 months) }\end{array}$ & $\begin{array}{c}95 \% \\
(91 \%)\end{array}$ & $\begin{array}{l}100 \% \\
(100 \%)\end{array}$ & $\begin{array}{l}45 \% \\
(3 \%)\end{array}$ & $\begin{array}{l}70 \% \\
(4 \%)\end{array}$ \\
\hline $\begin{array}{l}\text { Söletormos } \\
\text { et al. A }\{3\}\end{array}$ & $\begin{array}{l}2 \text { months } \\
\text { (2 months) }\end{array}$ & $\begin{array}{l}6 \text { months } \\
\text { (6 months) }\end{array}$ & $\begin{array}{l}14 \text { months } \\
\text { (14 months) }\end{array}$ & $\begin{array}{c}76 \% \\
(32 \%)\end{array}$ & $\begin{array}{c}98 \% \\
(70 \%)\end{array}$ & $\begin{array}{l}35 \% \\
(2 \%)\end{array}$ & $\begin{array}{l}65 \% \\
(3 \%)\end{array}$ \\
\hline $\begin{array}{l}\text { Chan } \\
\text { et al. }\{4\}\end{array}$ & $\begin{array}{l}{[4 \text { months }]^{1}} \\
\left([4 \text { months }]^{1}\right)\end{array}$ & $\begin{array}{l}8 \text { months } \\
\text { (8 months) }\end{array}$ & $\begin{array}{l}14 \text { months } \\
\text { (14 months) }\end{array}$ & $\begin{array}{c}65 \% \\
(64 \%)\end{array}$ & $\begin{array}{l}91 \% \\
(91 \%)\end{array}$ & $\begin{array}{c}6 \% \\
(0 \%)\end{array}$ & $\begin{array}{l}13 \% \\
(0 \%)\end{array}$ \\
\hline $\begin{array}{l}\text { Söletormos } \\
\text { et al. B }\{5\}\end{array}$ & $\begin{array}{l}{[4 \text { months }]^{1}} \\
\left([4 \text { months }]^{1}\right)\end{array}$ & $\begin{array}{l}8 \text { months } \\
\text { (8 months) }\end{array}$ & $\begin{array}{l}18 \text { months } \\
\text { (16 months) }\end{array}$ & $\begin{array}{l}19 \% \\
(6 \%)\end{array}$ & $\begin{array}{c}47 \% \\
(24 \%)\end{array}$ & $\begin{array}{l}3 \% \\
(0 \%)\end{array}$ & $\begin{array}{l}7 \% \\
(0 \%)\end{array}$ \\
\hline $\begin{array}{l}\text { Molina } \\
\text { et al. }\{6\}\end{array}$ & $\begin{array}{l}{[4 \text { months }]^{1}} \\
\left([4 \text { months }]^{1}\right)\end{array}$ & $\begin{array}{l}8 \text { months } \\
\text { (8 months) }\end{array}$ & $\begin{array}{l}16 \text { months } \\
\text { (16 months) }\end{array}$ & $\begin{array}{c}0 \% \\
(0 \%)\end{array}$ & $\begin{array}{c}0 \% \\
(0 \%)\end{array}$ & $\begin{array}{c}0 \% \\
(0 \%)\end{array}$ & $\begin{array}{c}0 \% \\
(0 \%)\end{array}$ \\
\hline $\begin{array}{l}\text { Nicolini } \\
\text { et al. }\{7\}\end{array}$ & $\begin{array}{l}{[4 \text { months }]^{1}} \\
\left([4 \text { months }]^{1}\right)\end{array}$ & $\begin{array}{c}{[8 \text { months }]^{2}} \\
\left([8 \text { months }]^{2}\right)\end{array}$ & $\begin{array}{c}{[14 \text { months }]^{4}} \\
\left([14 \text { months }]^{3}\right)\end{array}$ & $\begin{array}{l}16 \% \\
(6 \%)\end{array}$ & $\begin{array}{c}29 \% \\
(10 \%)\end{array}$ & $\begin{array}{c}0 \% \\
(0 \%)\end{array}$ & $\begin{array}{c}0 \% \\
(0 \%)\end{array}$ \\
\hline
\end{tabular}

1Three sample points are needed for the algorithm. ${ }^{2}$ Only at start concentrations below $57 \mathrm{U} / \mathrm{L}$ obtain $100 \%$. ${ }^{3}$ Only at start concentrations below $28 \mathrm{U} / \mathrm{L}$ obtain $100 \% .{ }^{4}$ Only at start concentration below $19 \mathrm{U} / \mathrm{L}$. Test of robustness of the algorithms when the biological variation, $\mathrm{CV}_{\mathrm{B}}$, is increased from $24.5 \%$ to $48.9 \%$. Times for detection of tumor progression using the different algorithms are listed for three slopes. Percentages false positive results (FP) after 1 and 2 years with TPA start concentrations below 95 $\mathrm{U} / \mathrm{L}$ and $57 \mathrm{U} / \mathrm{L}$ for each algorithm are also listed. All results are generated from 1000 computer simulations. Results from biological variation of $\mathrm{CV}_{\mathrm{B}}=48.9 \%$ and $\mathrm{CV}_{\mathrm{B}}=24.5 \%$ just below in (brackets).

Table 2. Performance of seven algorithms with increased biological variation.

On the other hand the results indicate that the algorithm from Molina et al. $\{6\}$ is most robust against increased biological variation $C_{B}$ values.

In the other extreme situation with a very low biological variation $5^{\text {th }}$ percentile $\left(\mathrm{CV}_{\mathrm{B}}=\right.$ $8.5 \%$ ), the performances from the algorithms are listed in Table 3.

The most striking results in the table is the impact from low biological variation $\mathrm{CV}_{\mathrm{B}}$ on the false positive number (FP) from algorithm Söletormos et al. A $\{3\}$ and algorithm Söletormos et al. B \{5\}. These algorithms show low percentage of FP results, when the biological variation $C_{B}$ is low - and on the other hand - a high number of FP results when the biological variation $\mathrm{CV}_{\mathrm{B}}$ is high, as discussed above. It should also be noted that the detection time for the slowest slope is two months earlier for Söletormos et al. A $\{3\}$, who at the same time show very low percentages of FP signals. In a clinical situation with a patient, where the biological variation is known to be low, the best algorithm for interpreting 
monitoring biomarker results will thus be the algorithm Söletormos et al. A $\{3\}$. In this situation very early detection times are combined with very low FP signals. It is notable that the algorithms $\{1\}$ Barak et al., $\{2\}$ Tondini and Hayes and $\{4\}$ Chan et al. for the high start concentrations have high percentages of FP after two years.

\begin{tabular}{|c|c|c|c|c|c|c|c|}
\hline Algorithm & $\begin{array}{l}\text { Slope 0.0907: } \\
100 \% \text { at time }\end{array}$ & $\begin{array}{l}\text { Slope } \\
0.0346: 100 \% \\
\text { at time }\end{array}$ & $\begin{array}{l}\text { Slope } 0.0123 \text { : } \\
100 \% \text { at time }\end{array}$ & $\begin{array}{l}\text { False- } \\
\text { positive } \\
\text { below } \\
95 \mathrm{U} / \mathrm{L} \\
\text { at } 1 \text { year }\end{array}$ & $\begin{array}{l}\text { False } \\
\text { positive } \\
\text { below } 95 \\
\text { U/L at } 2 \\
\text { years }\end{array}$ & $\begin{array}{l}\text { False } \\
\text { positive } \\
\text { below } 57 \\
\mathrm{U} / \mathrm{L} \text { at } 1 \\
\text { year }\end{array}$ & $\begin{array}{l}\text { False } \\
\text { positive } \\
\text { below } 57 \\
\text { U/L at } 2 \\
\text { years }\end{array}$ \\
\hline $\begin{array}{l}\text { Barak } \\
\text { et al. }\{1\}\end{array}$ & $\begin{array}{l}2 \text { months } \\
\text { (2 months) }\end{array}$ & $\begin{array}{l}6 \text { months } \\
(6 \text { months })\end{array}$ & $\begin{array}{l}12 \text { months } \\
\text { (12 months) }\end{array}$ & $\begin{array}{c}98 \% \\
(98 \%)\end{array}$ & $\begin{array}{l}100 \% \\
(100 \%)\end{array}$ & $\begin{array}{c}0 \% \\
(3 \%)\end{array}$ & $\begin{array}{c}0 \% \\
(4 \%)\end{array}$ \\
\hline $\begin{array}{l}\text { Tondini and } \\
\text { Hayes }\{2\}\end{array}$ & $\begin{array}{l}2 \text { months } \\
\text { (2 months) }\end{array}$ & $\begin{array}{l}6 \text { months } \\
\text { (6 months) }\end{array}$ & $\begin{array}{l}12 \text { months } \\
\text { (12 months) }\end{array}$ & $\begin{array}{c}65 \% \\
(91 \%)\end{array}$ & $\begin{array}{c}94 \% \\
(100 \%)\end{array}$ & $\begin{array}{c}0 \% \\
(3 \%)\end{array}$ & $\begin{array}{c}0 \% \\
(4 \%)\end{array}$ \\
\hline $\begin{array}{l}\text { Söletormos } \\
\text { et al. A }\{3\}\end{array}$ & $\begin{array}{l}2 \text { months } \\
\text { (2 months) }\end{array}$ & $\begin{array}{l}6 \text { months } \\
\text { (6 months) }\end{array}$ & $\begin{array}{l}12 \text { months } \\
\text { (14 months) }\end{array}$ & $\begin{array}{c}1 \% \\
(32 \%)\end{array}$ & $\begin{array}{c}1 \% \\
(70 \%)\end{array}$ & $\begin{array}{c}0 \% \\
(2 \%)\end{array}$ & $\begin{array}{c}0 \% \\
(3 \%)\end{array}$ \\
\hline $\begin{array}{l}\text { Chan } \\
\text { et al. }\{4\}\end{array}$ & $\begin{array}{l}{[4 \text { months }]^{1}} \\
\left([4 \text { months }]^{1}\right)\end{array}$ & $\begin{array}{l}8 \text { months } \\
\text { (8 months) }\end{array}$ & $\begin{array}{l}14 \text { months } \\
\text { (14 months) }\end{array}$ & $\begin{array}{c}68 \% \\
(64 \%)\end{array}$ & $\begin{array}{c}92 \% \\
(91 \%)\end{array}$ & $\begin{array}{c}0 \% \\
(0 \%)\end{array}$ & $\begin{array}{c}0 \% \\
(0 \%)\end{array}$ \\
\hline $\begin{array}{l}\text { Söletormos } \\
\text { et al. B }\{5\}\end{array}$ & $\begin{array}{l}{[4 \text { months }]^{1}} \\
\left([4 \text { months }]^{1}\right)\end{array}$ & $\begin{array}{l}8 \text { months } \\
\text { (8 months) }\end{array}$ & $\begin{array}{l}14 \text { months } \\
\text { (16 months) }\end{array}$ & $\begin{array}{c}0 \% \\
(6 \%)\end{array}$ & $\begin{array}{c}0 \% \\
(24 \%)\end{array}$ & $\begin{array}{c}0 \% \\
(0 \%)\end{array}$ & $\begin{array}{c}0 \% \\
(0 \%)\end{array}$ \\
\hline $\begin{array}{l}\text { Molina } \\
\text { et al. }\{6\}\end{array}$ & $\begin{array}{l}{[4 \text { months }]^{1}} \\
\left(\left[4 \text { months }^{1}\right)\right.\end{array}$ & $\begin{array}{l}8 \text { months } \\
(8 \text { months })\end{array}$ & $\begin{array}{l}16 \text { months } \\
\text { (16 months) }\end{array}$ & $\begin{array}{c}0 \% \\
(0 \%)\end{array}$ & $\begin{array}{c}0 \% \\
(0 \%)\end{array}$ & $\begin{array}{c}0 \% \\
(0 \%)\end{array}$ & $\begin{array}{c}0 \% \\
(0 \%)\end{array}$ \\
\hline $\begin{array}{l}\text { Nicolini } \\
\text { et al. }\{7\}\end{array}$ & $\begin{array}{l}{[4 \text { months }]^{1}} \\
\left(\left[4 \text { months }^{1}\right)\right.\end{array}$ & $\begin{array}{l}{[8 \text { months }]^{2}} \\
\left([8 \text { months }]^{2}\right)\end{array}$ & $\begin{array}{c}\text { [14 months }]^{2} \\
\left([14 \text { months }]^{3}\right)\end{array}$ & $\begin{array}{c}0 \% \\
(6 \%)\end{array}$ & $\begin{array}{c}0 \% \\
(10 \%)\end{array}$ & $\begin{array}{c}0 \% \\
(0 \%)\end{array}$ & $\begin{array}{c}0 \% \\
(0 \%)\end{array}$ \\
\hline
\end{tabular}

${ }^{1}$ Three sample points are needed for the algorithm. ${ }^{2}$ Only at start concentrations below $57 \mathrm{U} / \mathrm{L}$ obtain $100 \%$. ${ }^{3}$ Only at start concentrations below $28 \mathrm{U} / \mathrm{L}$ obtain $100 \%$.

Test of robustness of the algorithms when the biological variation is decreased from $\mathrm{CV}_{\mathrm{B}}=24.5 \%$ to $\mathrm{CV}_{\mathrm{B}}$ $=8.5 \%$. Times for detection of tumor progression using the different algorithms are listed for three slopes. Percentages false positive results after 1 and 2 years with TPA start concentrations below $95 \mathrm{U} / \mathrm{L}$ and $57 \mathrm{U} / \mathrm{L}$ for each algorithm are also listed. All results are generated from 1000 computer simulations. Results from biological variation of $\mathrm{CV}_{\mathrm{B}}=8.5 \%$ and $\mathrm{CV}_{\mathrm{B}}=24.5 \%$ just below in (brackets).

Table 3. Performance of seven algorithms with decreased biological variation.

In conclusion, the most robust algorithm against biological variation is the algorithm Molina el al. $\{6\}$. And the most sensitive algorithms with influence from biological variations $C_{B}$ are the algorithms Söletormos et al. A $\{3\}$ and Söletormos et al. B $\{5\}$.

\subsubsection{Biological variation of tumour growth}

Just as we have investigated the impact of biological variation, $\mathrm{CV}_{\mathrm{B}}$, on the performance in a steady-state situation, we have also challenged the variation in progression conditions. Thus, 
we have included a variation of $25 \%$ with the selected three slopes in the simulation model and compared the results with the results in Table 1.

Nearly all the results were close to the same as in Table 1 when this variation of $25 \%$ was included in the exponential function. The false positive (FP) results chanced only a few per cent for the most algorithms and maximum increases in percentages were $4 \%$ found at the algorithms Barak et al. $\{1\}$ and Tondini \& Hayes $\{2\}$ below $57 \mathrm{U} / \mathrm{L}$ after two years.

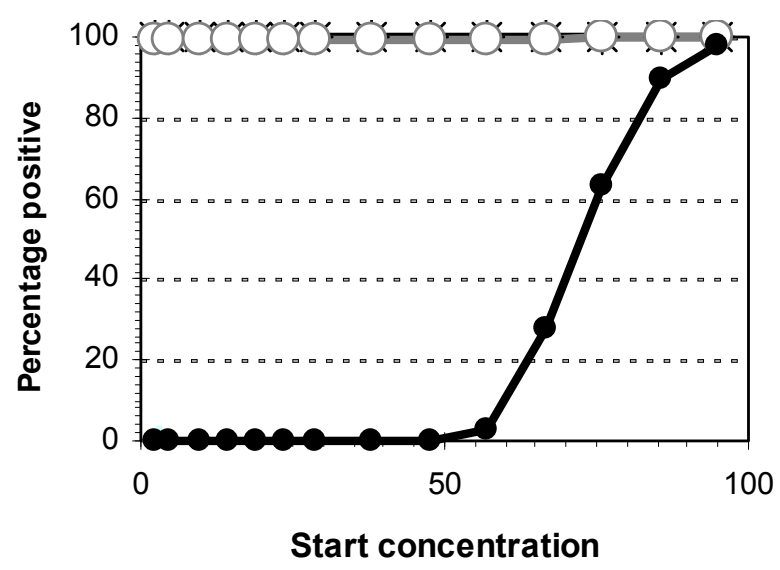

Algorithm:

Barak

Sample 7

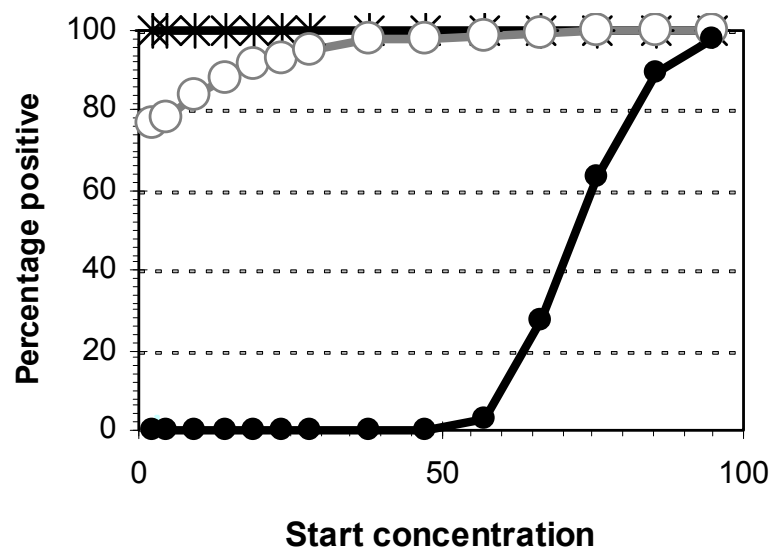

Algorithm:

Barak

Sample 7

Percentage positive patients (POS) as a function of starting concentrations for algorithm Barak et al. \{1\} after one year. The upper figure shows results from the "normal" rate of increase. The figure below shows results from a modified rate of increase, including biological variation in the exponential function of tumour growth of $25 \%$. For the slowest slope $(\lambda=0.0132)(---0---)$, the modified slope shows a reduced number of percentage positives from start concentration 0 up to approx $57 \mathrm{U} / \mathrm{L}$ TPA with percentage positives increasing from $78 \%$ to $100 \%$, respectively.

Fig. 7. Impact of biological variation on exponential tumour growth. 
Also the detection times for progression using the three slopes with biological variation were nearly the same as the results without variation. An example of the minor changes in results including variation of tumour growth is illustrated in Fig. 7. Results from the algorithm Barak et al.\{1\} include a variation of exponential function of $25 \%$; only the slowest slope for tumour growth shows a slightly reduced number of percentages of positive results compared to the "normal" slope. The most marked change was found with algorithm Söletormos et al. A $\{3\}$. This algorithm showed two months extended detection time at the middle fast slope $(\lambda=0.0346)$ - and similarly the algorithm Molina et al. $\{6\}$ showed two months extended detection time at the slowest slope.

Overall, the biological variation of tumour growth has only minimal effects on the results and does not change the conclusions based on results in Table 1; it may therefore be excluded from further computer simulation investigations.

\section{Conclusion}

The start concentration of the biomarker TPA is a very important parameter in the examination of the performance of the algorithm, i.e. time for detection of progression and percentage of false positive results (FP). Start concentrations near cut-off will give more FP in nearly every algorithm - but the algorithms with low FP results also have longer tumour detection time. All the investigated algorithms performed comparable in FP results, when the start concentration was low, i.e. below $57 \mathrm{U} / \mathrm{L}$.

These overall conclusions are relatively identical to the conclusion on results from the same algorithms using biomarker CA 15-3 (Petersen et al., 2011) - this indicates that the relative performance of algorithms is independent of the biomarker.

Differences in biological variation, $\mathrm{CV}_{\mathrm{B}}$, have an influence on the performance of nearly all the algorithms. Only the algorithm Molina et al $\{6\}$ has unchanged results with the different biological variations, $\mathrm{CV}_{\mathrm{B}}$, - in other words this algorithm is the most robust against increasing biological variation $\mathrm{CV}_{\mathrm{B}}$. Some algorithms show better performance when the biological variation $C_{B}$ is low. When the biological variation $C_{B}$ is low the algorithm Söletormos et al. A $\{3\}$ has the best performance as regards early progression detection and simultaneously low number of FP results.

The biological variation of the tumour growth up to $25 \%$ has only a minor influence on the performance of the algorithms and does not chance the overall conclusions.

In a clinical situation the start concentration should be the point for selecting the best algorithm. When the start concentration is near the cut-off, the algorithm Molina et al. \{6\} could be used to avoid too many FP results. When the start concentration is below $57 \mathrm{U} / \mathrm{L}$, the algorithm Barak et al. $\{1\}$ could be used to have a short progressive detection time with only few FP results.

\subsection{Computer simulations}

A summary of new important conclusions from this investigation:

a. The relative performances of algorithms are independent of the biomarker. 
b. Some algorithms are more robust against increased biological variation than others.

c. Variation in tumour growth has only limit impact on the performances of the algorithms.

These conclusions are based on computer simulations. In the computer simulations, the steady-state variation and the rate of tumour increase $(\lambda=$ slope $)$ are based on clinical data from the literature and the simulations are based on random counts generated from a Gaussian distribution from the computer multiplied by the parameters borrowed from publications. Furthermore, the cost-price for the clinical investigations compared with computer simulation is enormous and the computer simulation is a convenient, easy and quick method to compare algorithm performances based on the same simulated data-points. Thus, computer simulation should be a tool to select the "right" algorithm before a clinical investigation regarding for example low number of false positive (FP) signals. Computer simulations are thus not a substitute for clinical investigations, but a supplementary tool in helping to interpret biomarker variations and challenge the algorithms with extreme parameters in the model.

Thus, the advantage of computer simulations is that it is relatively easy to vary the parameters in the simulation model and examine the impact on the performances of the algorithms. In this investigation we have investigated these performances under standard conditions as well as under extremes with conditions of varied $C V_{B}$ in steady-state and varying slopes of tumour growth. In addition, we have tested the robustness of the algorithms by using extreme values for $C_{B}$ and we have tested for variation in the exponential slopes of tumour growth.

Parameters which interestingly could also be varied are sampling intervals or the starting points of the exponential tumour growth.

In this study we have chosen a sampling interval of every two months, which is a relevant time schedule for monitoring of patients with breast cancer during follow-up after treatment (Söletormos et al., 2000b). Obviously, a sampling interval of one month could give earlier detection of tumour growth progression. However, in many of the algorithms the number of FP signals will simultaneously increase, and, conversely, longer sampling intervals will reduce FP signals, but true signals will be delayed.

We have chosen arbitrarily the starting point of exponential tumour growth to be $1 \%$ of cutoff. The impact on the performances of the algorithms when varying this starting point for the contribution from the growing tumour may be comparable for all the algorithms. If, for example, a starting point of $50 \%$ of the cut-off concentration was selected - the time for crossing cut-off would be shortened, so the progression detection time would possibly be earlier, whereas the percentages of FP would be unchanged for all algorithms.

\subsection{Future research}

In this investigation, we have investigated and challenged the seven algorithms, but the effect of sampling interval and of the start value of the contribution of marker from the tumour has not been studied. Furthermore, this computer model for simulations can be used for evaluation of other algorithms which can be tested and compared to the existing algorithms, before they are published or introduced in the clinic. 


\section{References}

Barak, M., Steiner, M., Finkel, B., Abrahamson, J., Antal, S., \& Gruener, N. (1990). CA-15.3, TPA and MCA as markers for breast cancer, Eur J Cancer, 26, pp. 577-80

Bliss, CI. (1967). Statistics in Biology, McGraw-Hill Book Company, New York

Bonfrer, JMG. (1990). Working group on tumor marker criteria (WGTMC). Tumor Biol, 11, pp. 287-8

Chan, DW., Beveridge,RA., Muss, H., Fritsche, HA., Theriault, R., Kiang, D., et al.. (1997). Use of Truquantt BR radioimmunoassay for early detection of breast cancer recurrence in patients with stage II and stage III disesase. J Clin Oncol. 15, pp. 2322-8

Dinistrian, AM., Schwartz, MK., Greenberg, EJ., Smith, CA. \& Schwartz, DC. (1991) CA 15-3 and carcinoembryonic antigen in the clinical evaluation of breast cancer. Clin Chim Acta, 200, pp. 81-94

Harris, EK. \& Yasaka, T. (1983) On the calculation of a reference change for comparing two consecutive measurements. Clin Chem, 29, pp. 25-30

Iglesias, N., Hyltoft Petersen, P. \& Ricos, C. (2005). Power functions of the reference change value in relation to cut-off points, reference intervals and index of individuality. Clin Chem Lab Med, 43, pp. 441-8

Molina, R., Zanón, G., Filella, X., Moreno, F., Jo, J., Daniels M, et al. (1995) Use of serial carcinoembryonic antigen and CA 15-3 assays in detecting relapses in breast cancer patients. Breast Cancer Res Treat, 36, pp. 41-8

Mughal, AW., Hortobagyi, GN., Fritsche, HA., Buzdar, AU., Yap, HY. \& Blumenschein GR. (1983) Serial carcinoembryonic antigen measurements during treatment of metastatic breast cancer. JAMA, 249, pp.1881-6

Nicolini, A., Colombini, C., Luciani, L., Carpi, A. \& Giuliani L. (1991) Evaluation of serum CA 15-3 and TPA in the post-operative follow-up of breast cancer patients. $\mathrm{Br} \mathrm{J}$ Cancer, 64, pp.154-8

Petersen, PH., Sölétormos, G., Pedersen, MF. \& Lund F. Interpretation of increments in serial tumour biomarker concentrations depends on the distance of the baseline concentration from the cut-off. Clin Chem Lab Med, 49 pp. 303-10

Sölétormos, G., Fogh, JM., Sehested-Hansen, B., Spang-Thomsen, M., Schiøler, V., Dombernowsky, P. \& Skovgaard, T. (1997) Carcino-embryonic antigen in monitoring the growth of human colon adenocarcinoma tumour cells SK-CO-1 and HT-29 in vitro and in nude mice. Eur J Cancer, 33, pp.108-14

Sölétormos, G., Hyltoft Petersen, P. \& Dombernowsky P. (2000a) Assessment of CA 15.3, CEA and TPA concentrations during monitoring of breast cancer. Clin Chem Lab Med, 38, pp. 453-63

Sölétormos, G., Hyltoft Petersen, P. \& Dombernowsky P. (2000b) Progression criteria for cancer antigen 15.3 and carcinoembryonic antigen in metastatic breast cancer compared to computer simulation of marker data. Clin Chem, 46, pp. 939-49

Sölétormos, G., Nielsen, D., Schiøler, V., Skovsgaard, T. \& Dombernowsky P. (1996) Tumor markers cancer antigen 15.3 and carcinoembryonic antigen in the clinical evaluationof breast cancer. Clin Chem, 42, pp. 564-75 
Tondini, C. \& Hayes DF. (1989) Circulating tumor markers in breast cancer. Hematol Oncol Clin N Am, 3, pp. 653-74 


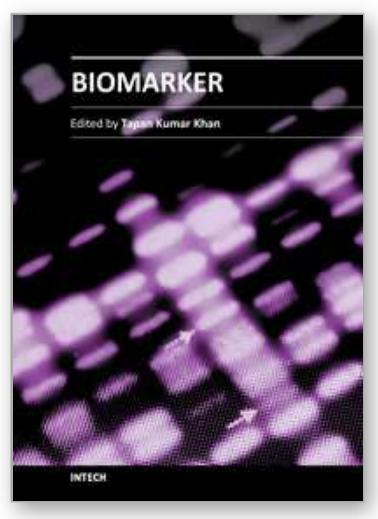

\author{
Biomarker \\ Edited by Prof. Tapan Khan
}

ISBN 978-953-51-0577-0

Hard cover, 392 pages

Publisher InTech

Published online 27, April, 2012

Published in print edition April, 2012

Clinicians, scientists, and health care professionals use biomarkers or biological markers as a measure of a person's present health condition or response to interventions. An ideal -biomarker should have the following criteria: (I) ability to detect fundamental features of the disease, (II) ability to differentiate from other closely related diseases, (III) ability to detect early stages and stages of progression, (IV) the method should be highly reliable, easy to perform and inexpensive, and (V) sample sources should be easily accessible from body. Most of the chapters in this book follow the basic principle of biomarkers.

\title{
How to reference
}

In order to correctly reference this scholarly work, feel free to copy and paste the following:

Flemming Lund, György Sölétormos, Merete Frejstrup Pedersen and Per Hyltoft Petersen (2012). Computer Simulation Model System for Interpretation and Validation of Algorithms for Monitoring of Cancer Patients by Use of Serial Serum Concentrations of Biomarkers in the Follow-Up After Surgical Procedures and Other Treatments - A Computer Simulation, Biomarker, Prof. Tapan Khan (Ed.), ISBN: 978-953-51-0577-0, InTech, Available from: http://www.intechopen.com/books/biomarker/computer-simulation-model-system-forinterpretation-and-validation-of-algorithms-for-monitoring-of-c

\section{INTECH}

open science | open minds

\section{InTech Europe}

University Campus STeP Ri

Slavka Krautzeka 83/A

51000 Rijeka, Croatia

Phone: +385 (51) 770447

Fax: +385 (51) 686166

www.intechopen.com

\section{InTech China}

Unit 405, Office Block, Hotel Equatorial Shanghai

No.65, Yan An Road (West), Shanghai, 200040, China

中国上海市延安西路65号上海国际贵都大饭店办公楼405单元

Phone: +86-21-62489820

Fax: $+86-21-62489821$ 
(C) 2012 The Author(s). Licensee IntechOpen. This is an open access article distributed under the terms of the Creative Commons Attribution 3.0 License, which permits unrestricted use, distribution, and reproduction in any medium, provided the original work is properly cited. 